\title{
ECPAS Gene
}

National Cancer Institute

\section{Source}

National Cancer Institute. ECPAS Gene. NCI Thesaurus. Code C158578.

This gene plays a role in proteasome assembly and localization. 